УДК 349.2:341.64:342.7:340.115:331.104

DOI https://doi.org/10.32849/2663-5313/2021.6.34

\title{
Наталія Клєцова,
}

канд. екон. наук, доиент

доцент кафедри міжнародних відносин

Сумського начіонального аграрного університету

Наталія Волченко,

канд. екон.наук, доцент,

дочент кафедри міжнародних відносин

Сумського національного аграрного університету

Анастасія Казбан,

студентка IV курсу спеиіальності «Міжнародне право»

Сумського національного аграрного університету

\section{НАУКОВЕ ДОСЛІДЖЕННЯ ПРАВА НА ПРАЦЮ: ПОРІВНЯННЯ МІЖНАРОДНОГО ДОСВІДУ ТА АКТУАЛЬНА ПРАКТИКА ЕСПЛ}

Статтю присвячено науковому дослідженню проблеми визначення права на прачю і свободи праиі, порівнянню міжнародного досвіду та практики ЄСПЛ щодо права на пращю, що є актуальною для юридичної громадськості не тільки в Україні, але й у зарубіжних країнах. Встановлено, що своєрідність розвитку економічної системи з певними кризовими проявами зумовлює питання про співвідношення конституційно-правового та міжнародно-правового регулювання таких найважливіших елементів механізму регулювання економічних відносин, як право на пращю і свобода прачі. У статті проаналізовано міжнародно-правові та регіональні трудові інструменти, положення Конституції України і трудового законодавства на предмет їхньої відповідності міжнародним правозахисним нормам у сфері праиі. Наведено та проаналізовано приклади судової практики Європейського суду з прав людини у сфері захисту трудових прав. Авторами було доведено, що право на пращю є базовим міжнародним стандартом, проголошеним Загальною декларачією прав людини. Аналіз міжнародноправових актів, що закріплюють право на пращю, дозволив виявити зміст даного поняття, яке включає право на вибір професії, право на недискриміначію, право на професійну орієнтачію, підготовку, перепідготовку та підвищення кваліфікаиії, право на підтримку трудящих, яке гарантуватиме реалізацію ними основних політичних і економічних свобод. Крім того, встановлено, що в конституціях зарубіжних країн законодавещь нерідко вибирає саме категорію «право на прачю» для закріплення правомочності громадян у сфері прачі. Доведено, що є нагальна потреба в повній реформі галузі прачі та регулювання трудових відносин в Украйні. Запропоновано в новаціях чинного трудового законодавства створення дійсно дієвого механізму реалізаиії й захисту трудових прав україниів, які відповідали б усім сучасним вимогам і міжнародним стандартам, насамперед Європейської сочіальної хартії.

Ключові слова: право на працю, свобода праці, реалізація права, міжнародні трудові стандарти, порівняння міжнародного досвіду, практика ЄСПЛ, наукове дослідження.

Постановка проблеми. Сучасні соціально-економічні умови - різноманіття форм власності, ринкові відносини, впровадження нових методів господарювання, свобода підприємницької діяльності, формування ринку праці - неминуче вносять суттєві зміни не лишу у зміст трудових відносин, але й у правове положення його суб'єктів, зокрема у зміст категорії «право на працю». 3 наукових позицій актуальність питання права на працю зумовлена насамперед реформою i динамікою трудового законодавства.Відсутність чіткої правової концепції регулювання трудових відносин працівників, що мають зобов'язальні права по відношенню до роботодавця, знижує рівень гарантій їхніх трудових прав. Наразі реалізація права на працю пов'язана 3 низкою гострих проблем, таких як дискримінація працівників, обмеження або утиск трудових прав, оплата праці, безробіття, трудова міграція. Оскільки право на працю є провідним питанням у сфері трудових відносин, то відповідно йому, як основоположному праву людини, приділяється особлива увага як на національному, зокрема юридичному, 
соціальному, так і на міжнародному рівні. Саме тому це питання є нагальним, повинно всебічно і принципово досліджуватися Тематика дослідження зумовлена потребою в науково-обгрунтованій системі правового визначення, реалізації та захисту права на працю і є запорукою гармонійних трудових відносин в нашій державі.

Аналіз останніх досліджень і публікацій. У сучасних умовах європейської інтеграції та ринкових принципів господарювання перед державою постає завдання відповідати європейським трудовим стандартам в забезпеченні умов і механізмів реалізації громадянами невід'ємного права на працю. У зв'язку з цим здійснюється переоцінка суспільством понять «праця», «право» і «свобода». Право на працю має складну природу, і тому питання про його поняття та нормативний зміст, засади здійснення цього права останнім часом активно досліджуються і публікуються такими вітчизняними правознавцями, як О.Ю Баханов [1], С.В. Венедіктов [2], Н.Д. Гетьманцева [3], О.О. Коваленко [4], С.О. Короєд [5], О.І. Процевський [6; 7], В.В. Хромей [8], М.О. Шумило [9], О.М. Ярошенко [10]. Так, С.В. Венедіктов [2], Н.Д. Гетьманцева [3], О.О. Коваленко [4] акцентують увагу на тому, що право на працю та його зміст є важливими елементами формування фундаменту сучасного трудового права. При цьому O.I. Процевський зазначає, що Конституція України вперше в історії держави встановила заборону примусової праці та визначила види трудової діяльності, які не вважаються примусовою працею [6, с. 252]. Більш того, О.Ю Баханов [1, с. 24] розглядає методи досягнення віддаленого надання послуг і прийняття рішень для задоволення потреб клієнтів без порушення при цьому права на працю найманого працівника. Щодо власного бачення підходів вище зазначених авторів, то можна стверджувати, що в працях зазначених вище вчених-юристів приділяється, зокрема, увага актуальним питанням співвідношення права на працю і свободи праці, взаємозв'язку права на працю і трудового договору. Але єдина позиція з цього питання відсутня. Так, законодавством багатьох держав Європи право на працю не включено до суб'єктивних прав людини, i, як наслідок, громадянин не правомочний вимагати надання роботи від держави.

Формування цілей статті. Метою даної статті є дослідження вітчизняного і міжнародного правового досвіду щодо визначення і здійснення права на працю, а також аналіз актуальної практики ЄСПЛ.
Виклад основного матеріалу. Зазначимо, що методологічну основу статті становлять порівняльно-правовий метод (наприклад, виявлення загального та особливого у праві на працю різних держав), метод вивчення i узагальнення міжнародно-правового досвіду, метод контент-аналізу. Категорія «право на працю» надає праці більш широкої загальноправової площини, відкриває можливості застосування юридичного інструментарію державної правової системи для реалізації і захисту цієї цінності людського буття. Важливість правового аналізу права на працю полягає і в тому, що це один із «фундаментів» громадянського суспільства, i, як зазначає O.M. Ярошенко, уся складна побудова суспільства й суспільних відносин будується на фундаменті праці, трудової діяльності в різних її проявах [10].

Конституція України та конституції зарубіжних країн передбачають основні права у сфері праці. Їхній зміст базується на міжнародних актах, що закріплюють права і свободи людини, і право на працю входить до переліку основних прав. Це невід'ємне і невідчужуване право, як і право на свободу слова, свободу думки, свободу пересування та ін. При цьому основний закон України проголошує право на працю, що включає можливість заробляти собі на життя працею, яку він вільно вибирає або на яку вільно погоджується. Для цього держава створює умови для повного здійснення громадянами права на працю, гарантує рівні можливості у виборі професії та роду трудової діяльності [11].

Зміст права на працю, що випливає 3 положень ст. 43 Конституції України, повною мірою узгоджується з міжнародними актами, в яких розкривається зміст права на працю. У них право на працю не пов'язується 3 отриманням гарантованої роботи, але закріплюється право на надання кожному можливості заробляти собі на життя працею, яку він вільно вибирає або на яку вільно погоджується. Отже, право на працю передбачає право на забезпечення можливості вибрати вид занять, рід діяльності, професію. Поряд із цим підкреслюється і необхідність сприяння пошуку роботи, створення умов для підвищення рівня зайнятості, а саме: держава створює умови для повного здійснення громадянами права на працю, гарантує рівні можливості у виборі професії та роду трудової діяльності, реалізовує програми професійно-технічного навчання, підготовки і перепідготовки кадрів відповідно до суспільних потреб [11].

Так, ст. 6 Міжнародного пакту про економічні, соціальні і культурні права 
1966 р. передбачає, що держави-учасники Пакту визнають право на працю, що включає право кожної людини дістати можливість заробляти собі на життя працею, яку він вільно обирає або на яку він вільно погоджується, і зроблять належні кроки до забезпечення цього права. Заходи, яких повинні вжити держави-учасниці цього Пакту 3 метою повного здійснення цього права, включають програми професійно-технічного навчання і підготовки, шляхи і методи досягнення продуктивної зайнятості в умовах, що гарантують основні політичні й економічні свободи людини [12]

Аналізуючи вищенаведену інформацію, ми можемо стверджувати, що складниками змісту права на працю, є свобода праці та право на отримання можливості заробити собі на життя працею, забезпечені певними державними заходами, включаючи шляхи і методи досягнення повної продуктивної зайнятості.

У ст. 7 Міжнародного пакту про економічні, соціальні і культурні права [12] йдеться про право кожного на справедливі та сприятливі умови праці, включаючи, зокрема: 1) винагороду, що забезпечувала $б$ як мінімум усім трудящим: справедливу зарплату і рівну винагороду за працю рівної цінності без будь-якої різниці, причому, зокрема, жінкам повинні гарантуватись умови праці, не гірші від тих, якими користуються чоловіки, з рівною платою за рівну працю; 2) задовільне існування для них самих та їхніх сімей відповідно до постанов цього Пакту; 3 ) умови роботи, що відповідають вимогам безпеки та гігієни; 4) однакову для всіх можливість просування по роботі на відповідні більш високі щаблі виключно на підставі трудового стажу і кваліфікації; 5) відпочинок, дозвілля і розумне обмеження робочого часу та оплачувану періодичну відпустку так само, як і винагороду за святкові дні [12].

Таким чином, ми хочемо підкреслити, що право на працю - це ще одне з економічних прав, наданих людині сучасним законодавством. Його сенс полягає в тому, що кожна людина має право працювати, вільно обирати місце роботи, має право на сприятливі і справедливі умови праці, захист від безробіття, гідну винагороду для людини і ї̈ сім’ї.

Варто зазначити, що стаття 23 Загальної декларації прав людини 1948 р. встановлює, що кожна людина має право на працю, на вільний вибір роботи, на справедливі та сприятливі умови праці й на захист від безробіття [13]. При цьому Декларація також закріплює права на рівну плату за виконану рівну працю, на справедливу винагороду, на створення і членство в професійних спілках. I саме Загальна декларація прав людини стала першим документом, в якому право на працю було проголошено як найважливіше міжнародне визнане право людини. Згодом Свропейська соціальна хартія 1961 р., проголошуючи право на працю, передбачила відповідні зобов'язання сторін, спрямовані на його реалізацію. Зокрема, в даному документі зроблено акцент на тому, що для забезпечення ефективної реалізації цього права сторони зобов'язуються: визнати однією зі своїх першочергових цілей і обов'язків досягнення і підтримання якомога високого і стабільного рівня зайнятості з метою досягнення повної зайнятості; забезпечити ефективний захист права працівників заробляти собі на життя вільно обраною працею; створити або розвивати для всіх працівників безкоштовні служби працевлаштування; забезпечувати або сприяти розвитку відповідної професійної орієнтації, професійної підготовки і перепідготовки [14]. Отже, ми бачимо, що Європейська соціальна хартія розширила та доповнила положення Загальної декларації прав людини.

Окрему увагу доцільно звернути й на те, що у Рекомендації Міжнародної організації праці № 169 «Про політику в галузі зайнятості» 1984 р. наголошується, що передбачене Конвенцією «Про політику в області зайнятості» 1964 р. і Рекомендацією «Про політику в галузі зайнятості» 1964 р. сприяння повній, продуктивній і вільно обраній зайнятості слід вважати засобом забезпечення на практиці здійснення права на працю [15]. Більш того, європейські стандарти прав людини, що гарантують реалізацію права на працю, втілені в міжнародних правозахисних актах регіонального рівня. Так, ст. 4 Конвенції «Про захист прав людини і основоположних свобод» 1950 р. забороняє рабство й примусову працю, зокрема, ніхто не може бути присилуваний виконувати примусову чи обов'язкову працю [16]. У ст. 5 Хартії основних прав Свропейського Союзу проголошено, що «ніхто не повинен залучатися до примусової чи обов'язкової праці», під чим слід розуміти будь-яку роботу або службу, яка вимагається від будь-якої особи під загрозою будь-якого покарання або нав'язливого заохочення і для якої ця особа не запропонувала добровільно своїх послуг [17]. Більш того, всебічне визнання державами-членами права на працю пов'язується зі здійсненням економічної і соціальної політики, мета якої - сприяння повній, продуктивній і вільно обраній зайнятості.

Варто зазначити, що право на працю різниться його нормативною фіксацією 
в зарубіжних державах. Так, країни з розвиненою демократією приділяють мало уваги закріпленню цього права в конституціях своїх держав або зовсім не приділяють іiі. Наприклад, США, Великобританія, Канада, Австрія, Норвегія, Данія тощо взагалі не приділяють уваги, оскільки це право вважається невід'ємним, тобто таким, що не піддається сумніву, правом кожної людини, і посягання на нього $є$ недопустимим. У країнах колишнього соціалістичного табору, зокрема у Польщі, Угорщині, Білорусі, Молдові, конституційне право людини на працю закріплюється досить широко, з встановленням цілої системи юридичних гарантій щодо рівності прав чоловіків і жінок, вільного вибору професії й роботи, заборони примусової праці, гідної та рівної винагороди, забезпечення належних, безпечних і здорових умов праці тощо. І відповідно, проблеми виникають переважно щодо шляхів його реалізації й захисту. Загалом у конституціях зарубіжних країн право на працю сформульовано декларативно, але в деяких зазначається обов'язок держави реалізувати та гарантувати це право. Наприклад, ст. 4 Конституції Італії «визнає за усіма громадянами право на працю та сприяє створенню умов, які забезпечують реальність цього права», а кожний громадянин «зобов'язаний < ...> здійснювати діяльність або функцію, що сприяють матеріальному або духовному прогресу суспільства». Стаття 22 Конституції Греції, зазначає, що держава турбується про створення умов для забезпечення повної зайнятості усіх громадян. Аналогічна норма міститься у Конституції Болгарії (ст. 48), Нідерландів (п. 1 ст. 19). Конституція Іспанії взагалі оголошує досягнення повної зайнятості одним з основоположних принципів соціально-економічної політики, а Конституція Фінляндії передбачає, що держава повинна забезпечувати роботою усіх громадян, які цього потребують, за винятком випадків, передбачених актами парламенту. У конституціях деяких західних країн право на працю проголошено у поєднанні з обов'язком працювати, а у конституціях Франції, Іспанії на перше місце ставиться саме цей обов'язок [8].

Міжнародним інструментом захисту трудових прав громадян слід вважати Європейський Суд 3 прав людини, оскільки його правові позиції виступають підставою такого захисту в національних судах. Компетенція Свропейського Суду в трудових спорах досить обмежена правами, гарантованими Європейською Конвенцією «Про захист прав людини і основних свобод». Судова практика у сфері захисту трудових прав загалом стосується заборони використання приму- сової праці та забезпечення права на свободу об’єднання та профспілкової діяльності. Очевидно, що Свропейська конвенція не містить норм, присвячених позбавленню можливості працювати, порядку та підставам припинення трудових відносин тощо. При цьому Європейський Суд в деяких справах визнавав звільнення і відсторонення працівників, що суперечать Конвенції, спираючись при цьому на норми ст. 8 про захист приватного і сімейного життя.

Так, постанова Європейського Суду у справі «Олександр Волков проти України» об'єднала існуючу практику в цільну позицію, згідно якої зона дії статті 8 Конвенції поширюється і на професійне життя людини, а обмеження, накладені на доступ до професії, так само як і звільнення, впливають на приватне життя (Oleksandr Volkov v. Ukraine, 09/01/2013, № $21722 / 11$, § 165, ECHR 2013; Özpinar v. Turkey, 19/10/2010, № 20999/04, §§ 43-48). У справі «Fernández Martínez проти Іспанії» Суд зазначив, що взаємодія між приватним життям stricto sensu і професійним життям була особливо важливою, оскільки характер професійної діяльності заявника і наступне звільнення безпосередньо вплинули на його поведінку в приватному житті [18]. Також Європейський Суд у деяких справах визнавав звільнення і відсторонення працівників, що суперечать Конвенції, спираючись при цьому на норми ст. 9 про свободу віросповідання («Eweida and Others v. The United Kingdom») [19], ст. 11 про свободу зібрань («Palomo Sánchez v. Spain») [20], а дуже часто навіть у поєднанні зі ст. 14 про заборону дискримінації.

\section{Висновки}

Таким чином, нами було доведено, що право на працю $є$ базовим міжнародним стандартом, проголошеним Загальною декларацією прав людини. Аналіз міжнародно-правових актів, що закріплюють право на працю, дозволив виявити зміст даного поняття, яке включає право на вибір професії, право на недискримінацію, право на професійну орієнтацію, підготовку, перепідготовку та підвищення кваліфікації, право на підтримку трудящих, яке гарантуватиме реалізацію ними основних політичних і економічних свобод. Нами було виявлено, що в конституціях зарубіжних країн законодавець нерідко вибирає саме категорію «право на працю» для закріплення правомочності громадян у сфері праці. Разом із тим нами доведено, що є нагальна потреба в повній реформі галузі праці та регулювання трудових відносин в Україні, зокрема, ми пропонуємо 
в новаціях чинного трудового законодавства створення дійсно дієвого механізму реалізації й захисту трудових прав українців, які б відповідали всім сучасним вимогам і міжнародним стандартам, насамперед Європейської соціальної хартії.

\section{Список використаних джерел:}

1. Баханов О. Ю. Захист соціальних працівників під час пандемії Covid-19. ВІСНИК НТУу «КПІ». Політологія. Соціологія. Право. 2020. Випуск 3 (47). С. 20-28. URL: http://visnykpsp.kpi.ua/article/view/227028 (дата звернення: 09.05.2021).

2. Венедіктов С. В. Правове регулювання праці у Великобританії: прогресивний досвід і перспективи для України : монографія. Київ : Ніка-Центр, 2017. 174 с

3. Гетьманцева Н. Д. Поняття і сутність праці як правової категорії. Підприємниитво, господарство і право. 2016. № 7 (245). C. 60-65. URL: http://nbuv.gov.ua/UJRN/Pgip_2016_7_11 (дата звернення: 16.05.2021).

4. Коваленко О. О. Актуальні проблеми сучасного розуміння права на працю. Науковий збірник Хмельнииького університету управління і права «Університетські наукові записки». 2016. № 59. C. 39-51.

5. Короєд С. О. Припинення трудових відносин у судовому порядку: процесуальний аспект формулювання працівником позовних вимог, Судова апеляиія. 2019. № 4. С. 47-57.

6. Процевський О. І. Чи справді держава не гарантує громадянам право на працю? Право України. 2014. № 1. С. 249-257.

7. Процевський В. О. Вплив принципу свободи праці при застосуванні правового припису ст. 38 КЗПП України. Збірник наукових пращь Харківського національного педагогічного університету імені Г. С. Сковороди. «Право». 2013. Вип. 20. С. 5-10.

8. Хромей В. В. Конституційне право на працю : монографія. Київ: Нац. торг.-екон. ун-т, 2018. $240 \mathrm{c}$.

9. Шумило М. О. Окремі аспекти сфери дії трудового законодавства. Судово-юридична газета. 13.09.2019. URL: https://sud.ua/ru/news/ blog/150070-okremi-aspekti-sferi-diyi-trudovogozakonodavstva-novi-pidkhodi-do-virishennya- deyakikh-kategoriy-trudovikh-sprav (дата звернення: 27.05.2021).

10. Ярошенко О. М. Основні напрями утвердження засад соціальної держави у трудовому праві. Право та інноваиіі. 2016. № 1 (13). C. 23-29. URL: https://dspace.nlu.edu. ua/handle/123456789/11280 (дата звернення: 26.05.2021).

11. Конституція України. Відомості Верховної Ради Украӥни. 1996. № 30. $141 \mathrm{c}$.

12. Міжнародний пакт про економічні, соціальні і культурні права / Верховна Рада України. 19.10.1973. URL: https://zakon.rada.gov.ua/laws/ show/995_042\#Text (дата звернення: 20.05.2021).

13. Загальна декларація прав людини. Резолюиія Генеральної Асамблеї ООН. № 217 від 10.12.1948 p. URL: https://zakon.rada.gov.ua/laws/ show/995 015\#Text (дата звернення: 01.16.2020).

14. Європейська соціальна хартія / Рада Європи. 1961 p. URL: https://zakon.rada.gov. ua/laws/show/994_300\#Text (дата звернення: 06.04.2021)

15. Рекомендації щодо політики в галузі зайнятості. Міжнародна організачія прачі. 1984 № 169. URL: https://zakon.rada.gov.ua/laws/ show/993_278\#Text (дата звернення: 24.03.2021).

16. Конвенція про захист прав людини і основоположних свобод. Рада Європи. 04.11.1950 р. Урядовий кур'єр. 2010. № 215. URL: https://zakon. rada.gov.ua/laws/show/995_004\#Text (дата звернення: 22.05.2021).

17. Хартія основних прав Європейського Союзу. EC. 2000. URL: https://zakon.rada.gov.ua/ laws/card/994_524 (дата звернення: 14.04.2021).

18. Довідник із застосування статті 8 Європейської конвенції з прав людини. Право на повагу до приватного і сімейного життя, житла кореспонденції. Свропейський Суд з прав людини. Страсбург. 2018. 118 c. URL: https://www.twirpx. com/file/3070809/ (дата звернення: 16.05.2021).

19. Case of Eweida and Others v. The United Kingdom. ECHR. Strasbourg. 25/05/2013. URL: https://hudoc.echr.coe.int/fre-press\#\{\%22ite mid\%22:[\%22001-115881\%22]\} (Last accessed: $05.05 .2021)$

20. Case Palomo Sánchez v. Spain. ECHR Strasbourg. 12/09/2011. URL: https://hudoc.echr. coe.int/eng\#\{\%22dmdocnumber\%22:[\%22891672 \%22],\%22itemid\%22:[\%22001-106178\%22]\} (Last accessed: 07.05.2021).

Nataliia Klietsova, Nataliia Volchenko, Anastasiia Kazban. Scientific research on the right to work: a comparison of international experience and current practice of the ECtHR

The article is devoted to scientific research on the problem of defining the right to work and freedom of labor, comparing international experience and current practice of the ECtHR on the right to work, which is relevant for the legal community not only in Ukraine but also abroad. It is established that the peculiarity of the development of the economic system with certain crisis manifestations determines the question of the relationship between constitutional and international legal regulation of such important elements of the mechanism of economic relations as the right to work and freedom of labour. The article analyzes international legal and regional labour instruments, the provisions of the Constitution of Ukraine and labour legislation for their compliance with international human rights standards in the field of labour. Examples of case law of the European Court of Human Rights in the field of labour rights protection are given and analyzed. The authors proved that the right to work is a basic international standard proclaimed by 
the Universal Declaration of Human Rights. The analysis of international legal acts enshrining the right to work revealed the meaning of this concept, which includes the right to choose a profession, the right to non-discrimination, the right to vocational guidance, training, retraining and advanced training, the right to support workers, basic political and economic freedoms. In addition, it was found that in the constitutions of foreign countries, the legislator often chooses the category of "right to work" to consolidate the competence of citizens in the field of labour. It is proved that there is an urgent need for full reform of the labour sector and regulation of labour relations in Ukraine. It was proposed in the innovations of the current labour legislation to create the truly effective mechanism for the implementation and protection of the Ukrainians' labour rights, which would meet all modern requirements and international standards, especially the European Social Charter.

Key words: right to work, freedom of labour, realization of law, international labour standards, comparison of international experience, practice of the European Court of Human Rights, scientific research. 